\title{
Evaluation of Muscle Chemical and Amino Acids Composition in Broiler Chicks Fed Sorghum or Sorghum-Pea Diets
}

\section{-Author(s)}

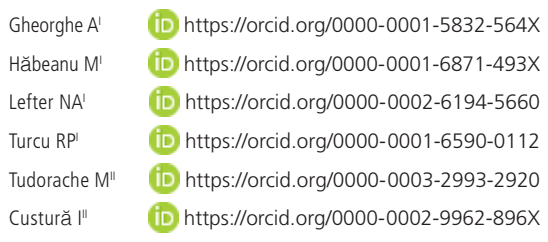

National Research-Development Institute for Biology and Animal Nutrition, Balotesti, 077015, Romania.

University of Agronomic Sciences and Veterinary Medicine of Bucharest, 59 Marasti Blvd, Bucharest, Romania.

\section{Mail Address}

Corresponding author e-mail address Anca Gheorghe

Laboratory of Animal Nutrition, National Research-Development Institute for Biology and Animal Nutrition, Balotesti, 077015, Romania.

Phone: (+40) 0213512081

Email: anca.gheorghe@ibna.ro

\section{aKeywords}

Amino acids, broiler, meat, peas, sorghum

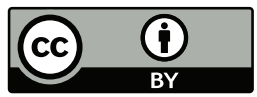

Submitted: 17/January/2021

Approved: 05/July/2021

\section{ABSTRACT}

The study evaluated the chemical and amino acids (AA) composition of breast and thigh muscle in broilers fed sorghum and sorghum-pea diets, as partial substitute of corn and soybean meal (SBM). A total of 540 3-wk-old broilers (Cobb 500) randomly assigned to three groups were fed with corn-SBM control diet (C), corn-sorghum-SBM diet (S) and corn-sorghum-peas-SBM diet (SP) for finisher phase. At slaughter, muscle samples were collected for chemical analyses. The results showed that dietary sorghum or sorghum-pea inclusion did not affect ( $p>0.05)$ the chemical composition (dry matter, protein, fat and ash) of broilers muscle tissue. The total AA (TAA), essential AA (EAA) or flavour-related AA (FAA) concentrations from breast or thigh muscle did not differ $(p>0.05)$ between treatments. A significant effect $(p<0.05)$ was found for some individual EAA. The valine and phenylalanine concentrations were higher, and cysteine and methionine levels were lower in both muscles than the $C$ group. The higher deposition $(p<0.05)$ was found for most $A A$, except glycine and arginine, in the breast vs thigh, as an effect of muscle tissue. As results, the TAA, EAA, NEAA, FAA and EAA/NEAA ratio increased in the breast vs thigh muscle. Interactions between diets and muscle tissue were noticed for serine, threonine, methionine, isoleucine, phenylalanine, lysine, arginine, TAA and EAA. In conclusion, sorghum or sorghum-peas can partially substitute the corn and SBM in broiler diets, with no adverse effects on chemical composition and beneficial nutrients, such as EAA and FAA that are important for the nutritional quality of meat.

\section{INTRODUCTION}

Nowadays, chicken meat is an important source for consumers due to the balanced nutritional components such as proteins, amino acids (AA), carbohydrates, polyunsaturated fatty acids (PUFA), minerals, vitamins, and lower fat content (Attia et al., 2016; Attia et al., 2017; Haraf et al., 2021). The price accessibility also promotes the production and consumption of chicken meat compared to red (beef or pork) meat (Jayasena et al., 2013a).

Moreover, modern consumers have become more attentive to meat quality and safety, including flavor and nutritional value, mainly due to health concerns (Attia et al., 2016; Zang et al., 2020). The quality of meat depends on the diet that is considered a key factor and on genotype, sex, birds age, and management system (Swiatkiewicz et al., 2017; Korish \& Attia, 2019). The link between broilers nutrition and meat quality has been extensively studied mainly by modulating the n-3 PUFA profile in meat to increase the consumption of these bio compounds by humans (Ribeiro et al., 2013; Attia et al., 2017). Dietary composition and nutrient contents are also potent regulators of muscle development and metabolism, muscle tissue mainly consists of muscle 
fiber, with a higher amount of protein (Grizard et al., 1999). Additionally, broilers meat protein is a rich source of all the essential amino acids (EAA; Soriano-Santos 2010) the main precursors of meat taste (Jayasena et al., 2013b) that comes from flavor substances such as AA and small peptides (Kato et al., 1989).

There is a continuous trend of using alternative energy-protein vegetable sources in broiler diets to replace conventional ingredients such as corn and soybean meal (SBM) due to climate change and the global demand. Genetically modified SBM had a higher price, and Romania also imported a large quantity. On the other hand, maintaining or improving meat quality characteristics remained a priority. Currently, the use of new varieties of home-grown sorghum and peas, with low levels of antinutrients in broiler diets have been researched. There are some studies on the effect of low-tannin sorghum (ground or whole) in broiler diets on performance, nutrient digestibility, gastrointestinal health and carcass traits (Fernandes et al., 2013; Garcia et al., 2013; Jacobs \& Parsons 2013; Torres et al., 2013; Tandiang et al., 2014; Silva et al., 2015; Gheorghe et al., 2017; Putingam et al., 2020) or peas (Laudadio \& Tufarelli 2010; Dotas et al., 2014; Gheorghe et al., 2019).
Fewer studies reported data on the chemical composition of broilers meat (Garcia et al., 2005; Carolino et al., 2014; Silveira et al., 2017) or meat quality, e.g., fatty acid profile, cholesterol, and vitamin $A$ and $E$ contents of meat (Ochieng et al., 2020) as an effect of feeding sorghum, or carcass and meat quality (Laudadio \& Tufarelli 2010; Dotas et al., 2014; Biesek et al., 2020) by feeding peas diets. However, no studies were found about the AA profile of meat in broilers fed sorghum or sorghum-peas diets.

Therefore, the study aimed to evaluate the effects of feeding sorghum or sorghum-peas in broilers diets, as partial substitute of corn or SBM, on the chemical composition and AA concentrations of specific muscles on broilers.

\section{MATERIAL AND METHODS}

\section{Nutritional value of sorghum and peas}

The sorghum (Sorghum bicolor L.) and pea (Pisum sativum L.) seeds were obtained from local crops. The nutritional composition of alternative feed ingredients used in the experiment is given in Table 1.

Table 1 - Nutritional composition of sorghum and peas used in diets ${ }^{1}$

\begin{tabular}{lcccccccccccccccccc}
\hline Item g kg & -1 & DM & CP & Lys & Met+ Cys & Tre & Arg & Ile & Fat & CF & Ash & NFE & Ca & P & ME \\
\hline Sorghum & 87.2 & 9.91 & 0.27 & 0.35 & 0.46 & 0.39 & 0.39 & 3.20 & 2.56 & 1.14 & 70.4 & 0.02 & 0.32 & 13.4 \\
Peas & 89.5 & 20.7 & 1.80 & 0.98 & 1.07 & 1.51 & 0.87 & 0.81 & 7.04 & 2.70 & 58.3 & 0.03 & 0.52 & 11.8
\end{tabular}

'Mean of duplicate analyses.

DM, dry matter; CP, crude protein; Lys, lysine; Met + Cys, methionine + cysteine; Tre, threonine; Arg, arginine; Ile, isoleucine; CF, crude fibre; NFE, nitrogen free extractive; Ca, calcium; P, phosphorus; $\mathrm{ME}$, metabolizable energy $\left(\mathrm{MJ} \mathrm{g} \mathrm{kg}^{-1}\right)$.

\section{Birds and experimental design}

A local Ethics Committee of the INCDBNA Balotesti, Romania, approved the trial protocol (7960/12/2019), following the EU Directive 2010/63/EU (OJEU, 2010).

Five hundred and forty mix-sexed 3-wk-old broilers (Cobb 500; 941.94 $\pm 4.92 \mathrm{~g}$ ), were used in a finisher phase ( 23 to $35 \mathrm{~d}$ ) feeding trial. Broilers were randomly allotted into three groups, with six replicates each (30 chicks), and kept in floor pens (wood shavings) equipped with manual feeders and nipple drinker lines. A photoperiod of $20 \mathrm{~h}$ light/4 $\mathrm{h}$ dark was provided during the trial. Feed, in mash form, and water were given ad libitum to the birds.

Dietary groups were: i). control (C) based on cornSBM, ii). sorghum (S) replaced $50 \%$ of corn and iii). sorghum-peas (SP) substituted $50 \%$ of corn and 35\% of SBM.

The formulated diets (Table 2) were isocaloric (13.34 MJ kg-1 ME) and isonitrogenous (180 $\mathrm{g} \mathrm{kg}^{-1}$ crude protein) and met the nutrients requirements of hybrid (Cobb-Vantress, 2015). The determined AA profile of diets is presented in Table 3.

\section{Muscle sampling}

On $35^{\text {th }}$ day of the trial, six broilers per group were randomly selected, and after $12 \mathrm{~h}$ of feed deprivation, were slaughtered by cervical dislocation. Breast and thigh muscles (without skin and bone) were ground (TC-121, Maxigel, Italy), and samples were stored at $-20^{\circ} \mathrm{C}$ until analyses. The chemical analyses described hereafter were determined in duplicate for the defrosted samples.

\section{Chemical analyses}

The proximate composition of the ingredients and diets samples were analyzed in duplicate for dry matter, crude protein, crude fat, crude fibre, ash, calcium, and phosphorus according to OJEU (2009) methods, as previously described by Gheorghe et al. (2020). 
Table 2 - Ingredients and chemical composition of experimental diets.

\begin{tabular}{|c|c|c|c|}
\hline \multirow[t]{2}{*}{ Item $\mathrm{g} \mathrm{kg}^{-1}$} & \multicolumn{3}{|c|}{ Finisher (23-35d) } \\
\hline & C & $\mathrm{S}$ & SP \\
\hline Corn & 657.6 & 332.7 & 263.0 \\
\hline Sorghum & 0 & 332.7 & 263.0 \\
\hline Peas & 0 & 0 & 200.0 \\
\hline Soybean meal & 220.0 & 210.0 & 144.0 \\
\hline Corn gluten meal & 36.0 & 35.0 & 36.0 \\
\hline Sunflower oil & 40.0 & 43.0 & 47.0 \\
\hline Monocalcium phosphate & 15.0 & 14.6 & 15.4 \\
\hline Calcium carbonate & 12.7 & 12.8 & 12.7 \\
\hline Salt & 3.0 & 3.0 & 3.0 \\
\hline DL-Methionine & 1.9 & 2.1 & 2.5 \\
\hline L-Lysine $\mathrm{HCl}$ & 3.2 & 3.5 & 2.4 \\
\hline Choline $\mathrm{HCl}$ & 0.6 & 0.6 & 0.6 \\
\hline Vitamin-mineral premix ${ }^{1}$ & 10.0 & 10.0 & 10.0 \\
\hline \multicolumn{4}{|l|}{ Calculated composition } \\
\hline $\left.\mathrm{ME}(\mathrm{MJ} \mathrm{kg})^{-1}\right)^{2}$ & 13.31 & 13.34 & 13.38 \\
\hline Crude protein & 180 & 180 & 180 \\
\hline Lysine, total & 10.5 & 10.5 & 10.5 \\
\hline Lysine, digestible & 9.5 & 9.5 & 9.5 \\
\hline Met + cys, total & 8.2 & 8.2 & 8.2 \\
\hline Met + cys, digestible & 7.4 & 7.4 & 7.4 \\
\hline Calcium & 7.6 & 7.6 & 7.6 \\
\hline Available phosphorus & 3.9 & 3.9 & 3.9 \\
\hline \multicolumn{4}{|l|}{ Analyzed composition } \\
\hline Dry matter & 883.5 & 885.9 & 885.3 \\
\hline Crude protein & 181.0 & 182.0 & 182.0 \\
\hline Crude fibre & 40.6 & 43.4 & 40.7 \\
\hline Crude fat & 61.6 & 62.3 & 63.9 \\
\hline Calcium & 7.6 & 7.7 & 7.8 \\
\hline Phosphorus total & 7.0 & 7.1 & 7.1 \\
\hline
\end{tabular}

C, control diet; S, sorghum diet; SP, sorghum-peas diet.

'Provided per kg diet: vitamin $A, 2.90$ mg; vitamin $D_{3}, 0.12$ mg; vitamin $E$, 50 mg; vitamin $\mathrm{K}_{3^{\prime}} 3 \mathrm{mg}$; vitamin $\mathrm{B}_{1^{\prime}} 2 \mathrm{mg}$; vitamin $\mathrm{B}_{2^{\prime}} 8 \mathrm{mg}$; vitamin $\mathrm{B}_{6^{\prime}} 3 \mathrm{mg}$; vitamin $\mathrm{B}_{1^{\prime}}$ $0.015 \mathrm{mg}$; vitamin $B_{5^{\prime}} 12 \mathrm{mg}$; vitamin $B_{3^{\prime}}, 50$ mg; vitamin $B_{9}, 1.5 \mathrm{mg} ; \mathrm{Mn}, 100 \mathrm{mg}$; $\mathrm{Zn}, 100 \mathrm{mg} ; \mathrm{Fe}, 40 \mathrm{mg} ; \mathrm{Cu}, 15 \mathrm{mg} ; \mathrm{I}, 1.0 \mathrm{mg} ; \mathrm{Se}, 0.30 \mathrm{mg} ; \mathrm{Co}, 0.25 \mathrm{mg} .{ }^{2}$ calculated acoording to NRC (1994).

Muscle (breast and thigh) samples were analyzed in duplicate for dry matter (ISO 1442:2010), protein (ISO 937:2007), fat (ISO 1444:2008) and ash (ISO 936:2009) contents (OJEU, 2009).

The amino acids analyses of the ingredients, feed and muscle samples were assessed in duplicate by high-performance liquid chromatography using an HPLC Surveyor Plus Thermo Electron and HyperSil BDS C18 column (Thermo Electron, Massachusetts, United States) of the following dimensions; $250 \mathrm{~mm} \times 4.6 \mathrm{~mm}$ x $5 \mu \mathrm{m}$ as previously described by Vărzaru et al. (2013). Briefly, the method consists of acid hydrolysis for the release of AA from the protein molecules, preceded by oxidation with performic acid for the sulphur AA. The following AA were determined: Asp, Glu, Ser, Gly, Ala, Tyr, Cys, Thr, Val, Met, lle, Leu, Phe, Lys, and Arg. The essential AA (EAA) was calculated by adding
Table 3 - Analyzed amino acid profile of experimental $\operatorname{diets}^{1}$

\begin{tabular}{lccc}
\hline \multirow{2}{*}{ Amino acids $\mathrm{g} \mathrm{kg}^{-1}$} & \multicolumn{3}{c}{ Finisher $(23-35 \mathrm{~d})$} \\
\cline { 2 - 4 } & $\mathrm{C}$ & $\mathrm{S}$ & $\mathrm{SP}$ \\
\hline Asp & 20.8 & 24.2 & 19.9 \\
Glu & 46.4 & 39.7 & 43.6 \\
Ser & 10.8 & 9.2 & 11.3 \\
Gly & 6.07 & 5.40 & 4.78 \\
Ala & 8.49 & 8.34 & 8.01 \\
Tyr & 5.48 & 5.32 & 5.94 \\
Cys & 3.09 & 2.95 & 2.83 \\
Thr & 7.18 & 7.75 & 7.53 \\
Val & 12.7 & 12.5 & 11.8 \\
Met & 3.82 & 3.79 & 3.84 \\
Ile & 8.86 & 8.7 & 7.46 \\
Leu & 10.1 & 14.2 & 14.0 \\
Phe & 7.02 & 7.87 & 9.20 \\
Lys & 8.85 & 8.82 & 8.81 \\
Arg & 8.34 & 7.37 & 8.10 \\
EAA & 66.9 & 70.9 & 70.7 \\
NEAA & 101 & 95.1 & 96.4 \\
\hline TAA & 168 & 166 & 167 \\
\hline C & & &
\end{tabular}

C, control diet; S, sorghum diet; SP, sorghum-peas diet.

'Mean of duplicate analyses.

EAA, esssential amino acids (Tre, Val, Met, lle, Leu, Phe, Lys, Arg).

${ }^{3} \mathrm{NEAA}$, non-essential amino acids (Asp, Glu, Ser, Gly, Ala, Tyr, Cys).

${ }^{4}$ TAA, total amino acids.

Tre, Val, Met, Ile, Leu, Phe, Lys, Arg, the non-essential AA (NEAA) by adding Asp, Glu, Ser, Gly, Ala, Tyr, Cys, whereas flavor-related AA (FAA) by adding Asp, Glu, Gly, Ala, Arg (Liu et al., 2015).

\section{Statistical analyses}

Data obtained were analysed by GLM procedure of SPSS (IBM SPSS Statistics version 20.0, 2011) using multifactor ANOVA ( 3 diets and 2 type of muscles) and means were separated using Tukey's method. The following linear model was used: Yijk $=\mu+$ SDi + DTj + $(D \times D T) i j$ + eijk, where Yijk = the dependent variables; $\mu=$ general mean; SDi $=$ effect of diet; $\mathrm{DTj}=$ effect of muscle type; $(D \times D T) i j=$ effect of the interaction between diet and muscle types; and eijk = random error. Each bird was considered the experimental unit for the determined analysis (breast and thigh muscle samples). Results are given as means and standard error of means (SEM). Statistical significance was considered at $p<0.05$.

\section{RESULTS AND DISCUSSION}

The meat's chemical composition is an important parameter in evaluating broiler meat quality, nutrient changes, and its health benefits. The present results show that the proximate composition (dry matter, 
protein, fat and ash) of breast and thigh meat did not change ( $p>0.05$ ) by the effect of the dietary sorghum or sorghum-peas inclusion in broilers diets (Table 4).

This is consistent with other studies that reported similar chemical composition of meat in broiler chickens fed sorghum (whole grain or ground) that replaced partially or totally corn (Garcia et al., 2005; Carolino et al., 2014) or in meat-type quail (Moraes et al., 2016). Comparing three nutritional programs with whole sorghum grain-based diets in Hubbard broilers, Silveira et al. (2017) reported values to range from $23.39-23.66 \%$ for protein and from $2.6-2.68 \%$ for fat contents of breast meat. Similarly, Dotas et al. (2014) found that the chemical composition of breast and leg muscles of Ross 308 broilers were not affected by feeding diets up to $480 \mathrm{~g} / \mathrm{kg}$ field peas, depending on the age, as partial substitute of SBM and corn. Laudadio \& Tufarelli (2010) showed that feeding Hubbard broilers with $400 \mathrm{~g} / \mathrm{kg}$ peas, from 14 to 49 $\mathrm{d}$ of age, lowers $(p>0.05)$ the protein content in the breast $(21.95 \%)$ and drumstick $(18.83 \%)$ muscle and significantly decrease the fat percentage around one point $(p<0.05)$ in the breast $(1.01 \%)$ and drumstick $(3.77 \%)$ compared with a conventional diet. Recently, Biesek et al. (2020) evaluated the effects of feeding Ross 308 broilers with $250 \mathrm{~g} / \mathrm{kg}$ of various legume seeds (peas, lupin, and faba beans) and rapeseed meal, and found a lower $(p<0.001)$ protein content and higher fat levels for breast and leg muscles in the peas and yellow lupin groups than the SBM group.

Poultry meat consists of 60 to $80 \%$ of water, 15 to $25 \%$ of protein, and 1.5 to $5.3 \%$ of lipids. It is known that the factors affecting the chemical composition of meat are diet, age, breeding environment, and anatomical cut. The most variable component is the fat content which is higher in the thigh than in the breast meat (Castellini et al., 2002).

Our results showed that the tissue effect was significantly $(p<0.0001)$ for protein and fat contents of meat, the breast had higher protein $(22.51 \%)$ and lower fat (1.24\%) contents compared with thigh meat (19.88\% and $3.29 \%)$. The chemical composition of meat obtained in our study are in line with international reference table on food composition (Anses-Ciqual, 2020; USDA, 2016) and previous research (Gheorghe et al., 2014). No interaction was found between diet and muscle tissue for proximate composition.

It was stated that the meat quality depends of many factors, but its amino acid profile is influenced by the species, the variety within the species or breed (Korish \& Attia, 2019; Gumulka \& Potlowicz, 2020). As shown in Table 5 regarding the AA composition of the muscle, the use of dietary sorghum and sorghum-peas as partial substitute of corn and SBM did not affect $(p>0.05)$ the total AA (TAA), essential AA (EAA) or flavour-related AA (FAA) concentrations from breast or thigh muscle. A significant effect of dietary treatments was found for some individual EAA; the Val and Phe concentrations were higher $(p<0.0001$, respectively $p=0.021)$, and Cys and Met levels were lower $(p<0.0001)$ in both muscles' tissues than $C$ group, although the diets had similar content of digestible sulphur AA.

To our knowledge, no data have been published on the effect of sorghum or sorghum-peas diets on the AA composition of chicken meat. Our results concerning the decreased Cys and Met concentrations of meat might partly explain by other reports that used lowtannin sorghum in broilers. Recently, Putingam et al. (2020) noted that partial or total replacement of corn by home-grown low-tannin sorghum in broiler diets had no adverse effects on performance and carcass traits only a negligible adverse impact on the apparent ileal digestibility of Met and Tyr. The authors explained these adverse effects as an impact of tannins on the AA bioavailability, especially on Met as methyl donor AA, which may be related to the detoxification of ingested tannins. Mansoori \& Acamovic (2007) tested the effect of increasing levels of tannic acid on the excretion of endogenous AA in broiler chickens and reported that the Met, His and Lys digestibility were reduced when

Table 4 - Chemical composition of muscle tissue of broilers fed soghum or sorghum-peas ${ }^{1}$

\begin{tabular}{|c|c|c|c|c|c|c|c|c|c|}
\hline Muscle & & Breast & & & Thigh & & SEM $^{2}$ & & lue \\
\hline Diet & $C$ & $S$ & SP & $C$ & $S$ & $S P$ & & Diet & Tissue \\
\hline Dry matter & 25.1 & 24.7 & 24.9 & 24.2 & 24.6 & 24.4 & 0.166 & 0.997 & 0.145 \\
\hline Protein & $22.7^{x}$ & $22.3^{x}$ & $22.6^{x}$ & $19.8^{y}$ & $20.0^{y}$ & $19.8^{y}$ & 0.312 & 0.987 & $<0.0001$ \\
\hline Fat & $1.27^{y}$ & $1.21^{y}$ & $1.23^{y}$ & $3.27^{x}$ & $3.18^{x}$ & $3.42^{x}$ & 0.220 & 0.650 & $<0.0001$ \\
\hline Ash & 1.16 & 1.11 & 1.13 & 1.07 & 1.09 & 1.06 & 0.012 & 0.298 & 0.114 \\
\hline
\end{tabular}

C, control diet; S, sorghum diet; SP, sorghum-peas diet.

'Mean of 6 birds/group, at $35 \mathrm{~d}$ of age.

${ }^{2} \mathrm{SEM}$, standard error of means.

xy Means within rows with different superscripts are significantly different $(p<0.05)$ for tissue effect. 
high tannic acid was used. The authors concluded that the higher excretion of Met and His vs other AA in response to tannic acid might be related to their high tannins affinity. Although our study results showed a decrease of the sulphur AA contents in muscle, there was no dietary treatments effect in TAA (81.01 and $79.77 \%$ in breast, respectively 74.33 and 74.06 in thigh), EAA (39.82 and $39.76 \%$ in breast, respectively 36.60 and 36.41 in thigh) or FAA (38.63 and $37.60 \%$ in breast, respectively 36.10 and 35.65 in thigh) concentrations vs C group (79.08, respectively $74.34 \%$ TAA, 38.67, respectively 36.19\% EAA, and 37.68, respectively $35.68 \%$ FAA). Kim et al. (2017) stated that broiler meat has up to $22 \%$ of protein, from which about $40 \%$ of the total AA being essential. According to Soriano-Santos (2010), broiler meat contains all the EAA and has a higher amount of Leu, Lys, Asp and Glu. Generally, AA are the main precursors of flavour substances of the meat. In particular, Glu mainly determines the taste of chicken meat. In addition to Glu, free aromatic AA (e.g., Phe and Tyr) have an essential role in enhancing the savoury or umami taste at sub-threshold concentrations in the presence of salt and free acidic AA (Wattanachant et al., 2004; Lioe et al., 2005; Huang et al., 2011). The FAA also includes Cys, Gly, Asp, Arg, and Ala (Liu et al., 2015).

In the present study, concerning the tissue effect (Table 5) a higher deposition $(p<0.05)$ for most AA was found, except for Gly and Arg, in the breast vs thigh muscle. Breast muscle had a higher Glu and Asp content, followed by Lys, Leu, Tre, Val, Ala, Ile, Phe, Ser, Tyr, Met and Cys. Almost the same trend was found in thigh muscle that had higher Glu and Asp concentrations, followed by Lys, Leu, Tre, Val, Ile, Phe, Ser, Ala, Tyr, Met and Cys. As results, the TAA (79.95 vs $74.25 \%)$, EAA (39.42 vs $36.40 \%)$, NEAA (40.54 vs

Table 5 - Amino acids profile of muscle tissue of broilers fed sorghum or sorghum-peas ${ }^{1}$

\begin{tabular}{|c|c|c|c|c|c|c|c|c|c|c|}
\hline \multirow{2}{*}{$\begin{array}{l}\text { Muscle } \\
\text { Diet }\end{array}$} & \multicolumn{3}{|c|}{ Breast } & \multicolumn{3}{|c|}{ Thigh } & \multirow[t]{2}{*}{$\mathrm{SEM}^{2}$} & \multicolumn{3}{|c|}{$p$-value } \\
\hline & $C$ & $S$ & $\mathrm{SP}$ & $C$ & $S$ & SP & & Diet & Tissue & $\mathrm{D} \times \mathrm{T}$ \\
\hline \multicolumn{11}{|c|}{$\overline{\text { Amino acids }}(\mathrm{g} / \overline{100 \mathrm{~g} \text { dry matter) }}$} \\
\hline Asp & $9.40^{x}$ & $9.73^{x}$ & $9.50^{x}$ & $8.86^{y}$ & $8.73^{y}$ & $8.60^{y}$ & 0.096 & 0.247 & $<0.0001$ & 0.092 \\
\hline Glu & $13.4^{x}$ & $13.6^{x}$ & $13.2^{x}$ & $12.8^{y}$ & $12.9^{y}$ & $12.8^{y}$ & 0.073 & 0.075 & 0.002 & 0.148 \\
\hline Ser & $3.94^{x}$ & $4.09^{x}$ & $3.91^{x}$ & $3.89^{y}$ & $3.79^{y}$ & $3.72^{y}$ & 0.031 & 0.080 & 0.003 & 0.012 \\
\hline Gly & 5.28 & 5.44 & 5.30 & 5.22 & 5.4 & 5.4 & 0.043 & 0.362 & 0.865 & 0.837 \\
\hline Ala & $4.52^{x}$ & $4.55^{x}$ & $4.37^{x}$ & $3.71^{y}$ & $3.74^{y}$ & $3.67^{y}$ & 0.085 & 0.143 & $<0.0001$ & 0.585 \\
\hline Tyr & $3.15^{x}$ & $3.17^{x}$ & $3.14^{x}$ & $3.12^{y}$ & $2.90^{y}$ & $2.89^{y}$ & 0.032 & 0.141 & 0.002 & 0.114 \\
\hline Cys & $0.724^{\mathrm{ax}}$ & $0.632^{b x}$ & $0.642^{b x}$ & $0.654^{\text {ay }}$ & $0.561^{\text {by }}$ & $0.565^{\text {by }}$ & 0.012 & $<0.0001$ & $<0.0001$ & 0.941 \\
\hline Thr & $5.49^{x}$ & $5.70^{x}$ & $5.42^{x}$ & $5.36^{y}$ & $4.97^{y}$ & $5.21^{y}$ & 0.058 & 0.458 & $<0.0001$ & 0.010 \\
\hline Val & $4.78^{\mathrm{cx}}$ & $5.07^{b x}$ & $5.28^{\mathrm{ax}}$ & $4.20^{c y}$ & $4.54^{\text {ay }}$ & $4.52^{\text {by }}$ & 0.080 & $<0.0001$ & $<0.0001$ & 0.289 \\
\hline Met & $1.70^{\mathrm{ax}}$ & $1.45^{b x}$ & $1.49^{b x}$ & $1.55^{\text {ay }}$ & $1.31^{\text {by }}$ & $1.31^{\text {by }}$ & 0.079 & $<0.0001$ & $<0.0001$ & $<0.0001$ \\
\hline Ile & $4.33^{x}$ & $4.31^{x}$ & $4.47^{x}$ & $4.15^{y}$ & $4.03^{y}$ & $3.83^{y}$ & 0.048 & 0.286 & $<0.0001$ & 0.002 \\
\hline Leu & $5.88^{x}$ & $5.94^{x}$ & $5.91^{x}$ & $5.39^{y}$ & $5.59^{y}$ & $5.48^{y}$ & 0.051 & 0.351 & $<0.0001$ & 0.129 \\
\hline Phe & $4.01^{c x}$ & $4.15^{b x}$ & $4.33^{a x}$ & $3.80^{c y}$ & $3.86^{\text {by }}$ & $3.94^{\text {ay }}$ & 0.039 & 0.021 & $<0.0001$ & 0.011 \\
\hline Lys & $7.41^{x}$ & $7.86^{x}$ & $7.59^{x}$ & $6.56^{y}$ & $6.68^{y}$ & $6.93^{y}$ & 0.109 & 0.183 & $<0.0001$ & 0.028 \\
\hline Arg & 5.08 & 5.34 & 5.28 & 5.08 & 5.36 & 5.19 & 0.043 & 0.957 & 0.748 & 0.040 \\
\hline TAA $^{3}$ & $79.1^{x}$ & $81.0^{x}$ & $79.8^{x}$ & $74.3^{y}$ & $74.3^{y}$ & $74.1^{y}$ & 0.651 & 0.251 & $<0.0001$ & 0.038 \\
\hline $\mathrm{EAA}^{4}$ & $38.7^{x}$ & $39.8^{x}$ & $39.8^{x}$ & $36.2^{y}$ & $36.6^{y}$ & $36.4^{y}$ & 0.369 & 0.495 & $<0.0001$ & 0.035 \\
\hline NEA $A^{5}$ & $40.4^{x}$ & $41.2^{x}$ & $40.0^{x}$ & $38.2^{y}$ & $38.7^{y}$ & $37.7^{y}$ & 0.300 & 0.103 & $<0.0001$ & 0.142 \\
\hline FAA $^{6}$ & $37.7^{x}$ & $38.6^{x}$ & $37.6^{x}$ & $35.7^{y}$ & $36.1^{y}$ & $35.7^{y}$ & 0.259 & 0.241 & $<0.0001$ & 0.121 \\
\hline $\begin{array}{l}\text { EAA } \\
\text { TAA }\end{array}$ & $0.489^{x}$ & $0.491^{x}$ & $0.498^{x}$ & $0.486^{y}$ & $0.492^{y}$ & $0.491^{y}$ & 0.001 & 0.082 & 0.003 & 0.759 \\
\hline $\begin{array}{l}\text { EAA } \\
\text { NEAA }\end{array}$ & $0.957^{x}$ & $0.967^{x}$ & $0.993^{x}$ & $0.948^{y}$ & $0.969^{y}$ & $0.967^{y}$ & 0.004 & 0.084 & 0.003 & 0.778 \\
\hline
\end{tabular}

C, control; S, sorghum; SP, sorghum-peas.

'Mean of 6 birds/group, at $35 \mathrm{~d}$ of age.

${ }^{2} \mathrm{SEM}$, standard error of means.

${ }^{3} \mathrm{TAA}$, total amino acids (AA).

${ }^{4}$ EAA, essential AA (Tre, Val, Met, lle, Leu, Phe, Lys, Arg).

${ }^{5}$ NEAA, non-essential AA (Asp, Glu, Ser, Gly, Ala, Tyr, Cys).

${ }^{6} \mathrm{FAA}$, flavor-related AA (Asp, Glu, Gly, Ala, Arg), calculated by Liu et al. (2015).

abc Means within rows with different superscripts are significantly different $(p<0.05)$ for diet effect.

${ }^{x y}$ Means within rows with different superscripts are significantly different $(p<0.05)$ for tissue effect. 
Gheorghe A, Hăbeanu M, Lefter NA, Turcu RP, Tudorache M, Custură I

\section{Evaluation of Muscle Chemical and Amino Acids Composition in Broiler Chicks Fed Sorghum or Sorghum-Pea Diets}

$37.85 \%)$, FAA (37.97 vs 35. 81\%) and EAA/ NEAA (0.97 vs 0.96$)$ ratio increased $(p<0.05)$ as well in the breast vs thigh muscle. Similarly, Haščík et al. (2020) reported that the breast contained higher amounts of all EAA and NEAA compared with thigh muscle of Ross 308 broilers. Sharipova et al. (2017) also found higher AA values in chicken meat, except for Lys and Tyr.

In our study, there was no adverse effect of dietary treatments or muscle tissue on the EAA/TAA ratios that were all higher than $40 \%$ and EAA/NEAA ratios that represented more than $60 \%$, these results suggesting that a good balance of AA was assured for broilers growth (Liu et al., 2015).

There were interactions between diet and muscle tissue for $\operatorname{Ser}(p=0.012)$, Thr $(p=0.010)$, Met $(p<0.0001)$, lle $(p=0.002)$, Phe $(p=0.011)$, Lys $(p=0.028)$, Arg $(p=0.040), \operatorname{TAA}(p=0.038)$ and EAA $(p=0.035)$.

In conclusion, sorghum or sorghum-peas can partially substitute the corn and SBM in broiler diets, with no adverse effects on chemical composition and beneficial nutrients, such as EAA and FAA that are important for the nutritional quality of meat. Moreover, the use of these home-grown ingredients in broiler diets represents an opportunity to increase economic efficiency, especially in the current context of climate change and the dependence of vegetable protein sources.

\section{ACKNOWLEDGMENTS}

This work was supported by the Ministry of Agriculture and Rural Development [grant ADER 8.1.9./ 2019], Romania.

\section{CONFLICT OF INTEREST}

The authors declare that there is no conflict of interest.

\section{REFERENCES}

Anses-Ciqual. French agency for food, environmental and occupational health \& safety. French food composition table version 2020 [cited 2020 Nov 30]. Available from: https://ciqual.anses.fr/.

Attia YA, Al-Harthi MA, Korish MA, Shiboob MM. Fatty acid and cholesterol profiles, hypocholesterolemic, atherogenic, and thrombogenic indices of broiler meat in the retail market. Lipids in Health and Disease 2017; 16:40.

Attia YA, Al-Harthi MA, Korisha MA, Shiboo MM. Evaluation of the broiler meat quality in the retail market: Effects of type and source of carcasses. Revista Mexicana de Ciencias Pecuarias 2016;7(3):321-339.

Biesek J, Kuźniacka J, Banaszak M, Kaczmarek S, Adamski M, Rutkowski A, et al. Growth performance and carcass quality in broiler chickens fed on legume seeds and rapeseed meal. Animals 2020;10:846.
Carolino ACXG, Silva MCA, Litz FH, Fagundes NS, Fernandes EA. Rendimento e composição de carcaça de frangos de corte alimentados com dietas contendo sorgo grão inteiro. Bioscience Journal 2014;30(4):1139_ 1148

Castellini C, Mungai C, Dal Bosco A. Effect of organic production system on broiler carcass and meat quality. Meat Science 2002;60:219-225.

Cobb-Vantress. COBB 500 broiler performance and nutrition supplement. July 2015 .

Dotas V, Bampidis VA, Sinapis E, Hatzipanagiotou A, Papanikolaou K. Effect of dietary field pea (Pisum sativum L.) supplementation on growth performance, and carcass and meat quality of broiler chickens. Journal of Livestock Science 2014;164:135-143.

Fernandes EA, Pereira WJS, Hackenhaar L, Rodrigues RM, Terra R. The use of whole grain sorghum in broiler feeds. Brazilian Journal of Poultry Science 2013;15(3):217-222

Garcia RG, Mendes AA, Andrade C, Paz ICLA, Takahashi SE, Pelicia K, et al. Avaliação do desempenho e de parâmetros gastrintestinais de frangos de corte alimentados com dietas formuladas com sorgo alto tanino e baixo tanino. Ciência e Agrotecnologia 2005;29(6):1248-1257.

Garcia RG, Mendes AA, Almeida Paz ICL, Komiyama CM, Caldara FR, Nääs $I A$, et al. Implications of the use of sorghum in broiler production. Brazilian Journal of Poultry Science 2013;15(3):169-286.

Gheorghe A, Lefter NA, Idriceanu L, Ropotă M, Hăbeanu M. Effects of dietary extruded linseed and Lactobacillus acidophilus on growth performance, carcass traits, plasma lipoprotein response, and cecal bacterial populations in broiler chicks. Italian Journal of Animal Science 2020;19(1):822-832.

Gheorghe A, Hăbeanu M, Tabuc C, Marin M. Effects of dietary pea seeds (Pisum Sativum L. Cv. Tudor) on performance, carcass traits, plasma biochemistry and intestinal microflora in broiler chicks. AgroLife Scientific Journal 2019;8(1):99-106.

Gheorghe A, Hăbeanu M, Olteanu M, Turcu RP, Dragomir C. Effects of dietary sorghum and triticale on performance, carcass traits and meat pH in broiler chickens. Food and Feed Research 2017;44(2):181-187.

Gheorghe A, Ciurescu G, Ropotă M, Hăbeanu M, Lefter NA. Influence of dietary protein levels and protein-oleaginous sources on carcass parameters and fatty acid composition of broiler meat. Archiva Zootechnica 2014;17(1):41-53

Grizard J, Dardevet D, Balage M, Larbaud D, Sinaud S, Savary I, et al. Insulin action on skeletal muscle protein metabolism during catabolic states. Reproduction, Nutrition, Development 1999;39:61-74.

Gumułka M, Połtowicz K. Comparison of carcass traits and meat quality of intensively reared geese from a Polish genetic resource flock to those of commercial hybrids. Poultry Science 2020;99(2):839-847.

Haraf G, Wołoszyn J, Okruszek A, Goluch Z, Wereńska M, Teleszko M. The protein and fat quality of thigh muscles from Polish goose varieties. Poultry Science 2021;100(4):100992.

Haščík P, Pavelková A, Tkáčová J, Čuboň J, Kačániová M, Habánová M,Mlyneková E. The amino acid profile of broiler chicken meat after dietary administration of bee products and probiotics. Biologia 2020;75:1899-1908

Huang A, Li J, Shen J, Tao Z, Ren J, Li G, et al. Effects of crossbreeding on slaughter traits and breast muscle chemical composition in chinese chickens. Brazilian Journal of Poultry Science 2011;13:247-253.

Jacobs C, Parsons CM. The effects of coarse ground corn, whole sorghum and a prebiotic on growth performance, nutrient digestibility, and cecal microbial populations in broilers fed diets with and without corn distillers dried grains with soluble. Poultry Science 2013;92:2347-2357. 
Jayasena DD, Jung S, Kim HJ, Bae YS, Yong HI, Lee JH, et al. Comparison of quality traits of meat from Korean native chickens and broilers used in two different traditional Korean cuisines. Asian-Australasian Journal of Animal Sciences 2013a;26:1038-1046.

Jayasena DD, Ahn DU, Nam KC, Jo C. Flavour chemistry of chicken meat: A review. Asian-Australasian Journal of Animal Sciences 2013b;26(5):732-742.

Kato $H$, Rhue MR, Nishimura T. Role of free amino-acids and peptides in food taste. In: Teranishi R, Buttery RG, Shahidi F, editors. Flavor chemistry: trends and developments. Washington: American Chemical Society; 1989. p.158-174.

Kim H, Do H, Chung $\mathrm{H}$. A comparison of the essential amino acid content and the retention rate by chicken part according to different cooking methods. Korean Journal for Food Science of Animal Resources 2017;37:626-634.

Korish MA, Attia YA. Protein and amino acid profiles of frozen and fresh broiler meat. Animal Science Papers \& Reports 2019;37(4):419-431.

Laudadio V, Tufarelli V. Growth performance and carcass meat quality of broiler chickens fed diets containing micronized-dehulled peas (Pisum sativum cv. Spirale) as a substitute of soybean meal. Poultry Science 2010;89:1537-1543

Lioe HN, Apriyantono A, Takara K, Wada K, Yasuda M. Umami taste enhancement of $\mathrm{MSG} / \mathrm{NaCl}$ mixtures by sub-threshold $\mathrm{L}$ - $\alpha$-aromatic amino acids. Journal of Food Science 2005;70:S401-S405.

Liu Y, Li F, Kong X, Tan B, Li Y, Duan Y, et al. Signaling pathways related to protein synthesis and amino acid concentration in pig skeletal muscles depend on the dietary protein level, genotype and developmental stages. PLoS One 2015;10:e0138277.

Mansoori B, Acamovic T. The effect of tannic acid on the excretion of endogenous methionine, histidine and lysine with broilers. Animal Feed Science and Technology 2007;134(3-4):198-210.

Moraes CA, Fernandes EA, Silveira MM, Martins JMS, Litz FH, Saar AGL, et al. Performance and meat chemical composition of quails fed with different sorghum levels instead of corn. Ciência Rural 2016;46(5): 933-936.

NRC - National Research Council. Nutrient requirements of poultry. $9^{\text {th }}$ rev ed. Washington: The National Academies Press; 1994.

OJEU - Official Journal of the European Union. Laying down the methods of sampling and analysis for the official control of feed [Commission Regulation (EC) No. 152/2009]. Bruxelas; 2009.

OJEU - Official Journal of the European Union. Directive 2010/63/EU of the european parliament and of the council on the protection of animals used for scientific purposes. OJEU 20.10.2010, Series L 276, 33-79. Bruxelas; 2010

Ochieng BA, Owino WO, Kinyuru JN, Mburu JN, Gicheha MG. Effect of low tannin sorghum based feeds on broiler meat nutritional quality. Journal of Agriculture and Food Research 2020;2:100078.

Puntigam R, Brugger D, Slama J, Inhuber V, Boden B, Krammer V, et al. The effects of a partial or total replacement of ground corn with ground and whole-grain low-tannin sorghum (Sorghum bicolor L. Moench) on zootechnical performance, carcass traits and apparent ileal amino acid digestibility of broiler chickens. Livestock Science 2020;104187.

Ribeiro T, Lordelo MM, Alves SP, Bessa RJB, Costa P, Lemos JPC, et al. Direct supplementation of diet is the most efficient way of enriching broiler meat with $n-3$ long-chain polyunsaturated fatty acids. British Poultry Science 2013;54(6):753-765.

Sharipova A, Khaziev D, Kanareikina S, Kanareikin V, Rebezov M, Kazanina $M$, et al. The effects of a probiotic dietary supplementation on the amino acid and mineral composition of broilers meat. Annual Research \& Review in Biology 2017;21(6):1-7.

Silva MCA, Carolino ACXG, Litz FH, Fagundes NS, Fernandes EA, Mendonça GA. Effects of sorghum on broilers gastrointestinal tract. Brazilian Journal of Poultry Science 2015;17(1): 95-102.

Silveira MM, Martins JMS, Litz F, Carvalho CMC, Moraes CA, Silva MCA, et al. Effect of sorghum based nutritional programs on performance, carcass yield and composition of breast in broilers. Brazilian Journal of Poultry Science 2017;043-050. Special Issue Nutrition

Soriano-Santos J. Chemical composition and nutritional content of raw poultry meat. In: Guerrero-Legarreta I, editor. Handbook of poultry science and technology. Hoboken: John Wiley \& Sons; 2010. p.467491.

SPSS. Statistics version 20.0. IBM SPSS; 2011.

Swiatkiewicz S, Arczewska-Włosek A, Józefiak, D. The nutrition of poultry as a factor affecting litter quality and foot pad dermatitis-An updated review. Journal of Animal Physiology and Animal Nutrition 2017; 101:e14-e20.

Tandiang D, Diop M, Dieng A, Louis G, Cisse N, Nassim M. Effect of corn substitution by sorghum grain with low-tannin content on broiler production: animal performance, nutrient digestibility and carcass characteristics. International Journal of Poultry Science 2014;13:568574.

Torres KAA, Pizauro JM Jr, Soares CP, Silva TGA, Nogueira WCL, Campos $D M B$, et al. Effects of corn replacement by sorghum in broiler diets on performance and intestinal mucosa integrity. Poultry Science 2013;92:1564-1571.

USDA - United States Department of Agriculture. USDA food composition database. 2016. [cited 2020 Nov 30]. Available from: https://ndb.nal. usda.gov/ndb/.

Vărzaru I, Untea AE, Martura T, Olteanu M, Panaite TD, Schitea M, et al. Development and validation of an RP-HPLC method for methionine, cysteine and lysine separation and determination in corn samples. Revista de Chimie 2013;64(7):673-679.

Wattanachant S, Benjakul S, Ledward D. Composition, color, and texture of thai indigenous and broiler chicken muscles. Poultry Science 2004;83:123-128.

Zhang C, Wang C, Zhao X, Chen K, Geng Z. Effect of L-theanine on meat quality, muscle amino acid profiles, and antioxidant status of broilers. Animal Science Journal 2020;91:e13351. 
